\title{
Airborne PCB patterns and urban scale in the Southern Río de la Plata Basin, Argentina
}

\author{
Malena J. Astoviza $^{\text {a,b,*, Natalia Cappelletti }}{ }^{\text {a,b }}$, Claudio Bilos ${ }^{\text {a }}$, Maria C. Migoya ${ }^{\text {a,b }}$, Juan C. Colombo ${ }^{\text {a,c }}$

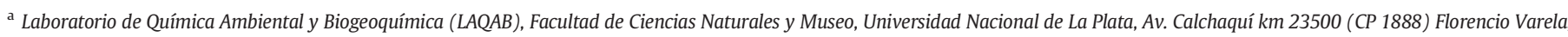 \\ Buenos Aires, Argentina \\ ${ }^{\mathrm{b}}$ Consejo Nacional de Investigaciones Científicas y Técnicas (CONICET), Argentina \\ c Comisión de Investigaciones Científicas, Provincia de Buenos Aires (CIC), Argentina
}

\section{H I G H L I G H T S}

- First regional scale assessment of airborne PCBs in the Río de la Plata basin

- Atmospheric PCB concentrations range in a low/very low global level.

- Spatial pattern confirms the role of urbanization scale in airborne PCB pollution.

- Lighter compositional pattern suggests an actual re-emission PCBs in urban sites.

- Aged background signal prevails in distant rural sites.

\section{A R T I C L E I N F O}

\section{Article history:}

Received 28 May 2016

Received in revised form 14 July 2016

Accepted 14 July 2016

Available online $\mathrm{xxxx}$

\section{G R A P H I C A L A B S T R A C T}

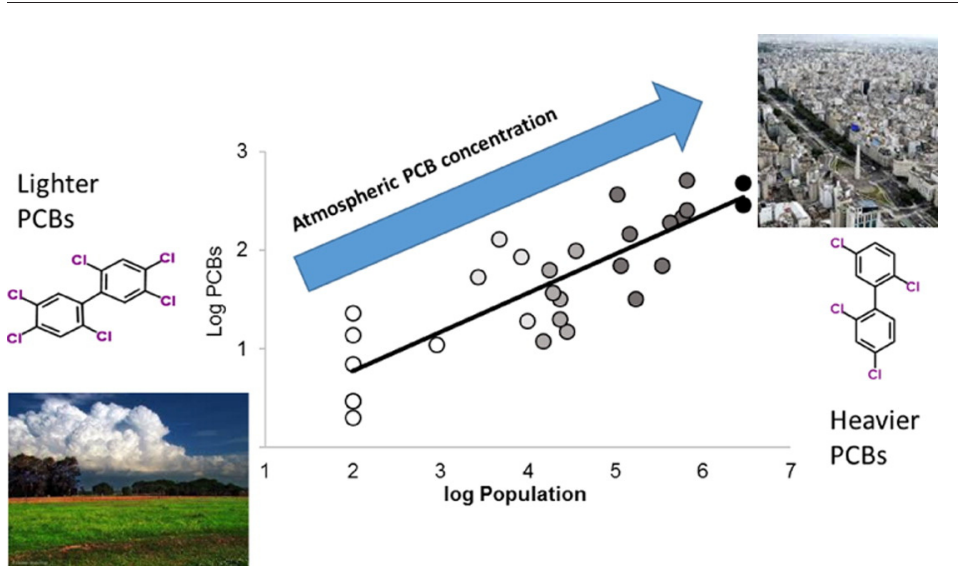

\begin{abstract}
A B S T R A C T
Atmospheric Polychlorinated Biphenyls (PCBs: $\sum 42$ congeners) collected by polyurethane passive samplers (PAS-PUFs) in 29 stations from July 2010 to February $2014(n=141)$ in the most productive and populated Southern Rio de la Plata area in Argentina were evaluated to assess concentration gradients, potential sources and compositional profiles related to different land use and urbanization. On a global scale, total airborne PCBs concentrations are low/very low (below detection limit to $937 \mathrm{pg} \mathrm{m}^{-3}$ ) and show a significant potential correlation with urban scale increasing 2.5 times each 10 times increase of population reflecting the primary role of urbanization controlling PCB emissions. Compositional patterns evaluated by principal component analysis (PCA) of individual congeners indicated that highly populated atmospheres are enriched in lighter, more volatile tri, tetra and penta chlorine congeners of lighter Aroclor mixtures (from 1242 to 1254) suggesting actual emission of fresh PCBs signatures from sealants, combustion and/or electrical equipment. Sub urban and rural sites show a gradual transition to heavier Aroclor mixtures (from 1254 to 1260) with predominance of more persistent hexa and hepta PCBs indicating an aged background signal resulting from long range transport and/or reemission from historic reservoirs such as soils.
\end{abstract}

(c) 2016 Elsevier B.V. All rights reserved.

\footnotetext{
* Corresponding author at: Laboratorio de Química Ambiental y Biogeoquímica (LAQAB), Facultad de Ciencias Naturales y Museo, Universidad Nacional de La Plata, Av. Calchaquí km 23500 (CP 1888) Florencio Varela, Buenos Aires, Argentina.

E-mail address: m.j.astoviza@fcnym.unlp.edu.ar (M.J. Astoviza).
} 


\section{Introduction}

Polychlorinated biphenyls (PCBs) have been produced on an industrial scale since 1930 and have been exported to virtually every country in the world (Breivik et al., 2002). They were commonly used in closed systems such as electrical transformers and capacitors and open applications as additives in several building materials (lubricating and cutting oils, paints, adhesives, sealants and plastics; UNEP, 1999; ATSDR, 2002; Park et al., 2002). Because of their chemical and physical properties (persistence, toxicity, moderate volatility, long half-lives, lipophilicity, hydrophobicity) they were classified as Persistent Organic Pollutants (POPs) by the Stockholm Convention and carcinogens to humans by the International Research Agency on Cancer (IARC, 2015). In this line, the biological activity of twelve non-ortho and monoortho PCBs (dioxin-like PCBs or dl-PCBs) which exerts a similar action to the highly toxic 2,3,7,8-tetrachlorodibenzo-p-dioxin resulted in the adoption of an equivalent toxicity scheme to comparatively evaluate possible health risks (TEFs; Van den Berg et al., 2006). Although PCBs production has globally ceased in 90s (Breivik et al., 2007), they are still distributed in the environment along dynamic, continuous cycles of volatilization from water and soils, long range transport through the atmosphere and removal to aquatic and terrestrial ecosystems via wet/dry deposition (Dobson and van Esch, 1993). Cities are main sources of PCBs due to the out-gassing of PCBs from buildings and leakage from closed systems such as older electrical equipment (Halsall et al., 1995; Harner et al., 2004).

In order to assess airborne PCBs concentrations, as well as human exposure and risk associated to inhalation at local, regional and global scales, in last decades air monitoring studies have been carried out using both active (Colombo et al., 2013; Gregoris et al., 2014), and passive samplers (Xu et al., 2013; Villavert et al., 2014; Cappelletti et al.,
2015). Among these latter devices, Polyurethane Foam disk passive samplers (PUFs) have proved to be very efficient because of their high retention capacity of POPs, low costs and simple handling.

While PCBs have been never produced in Argentina, nearly 3100 tonnes have been imported into the country (Breivik et al., 2002). In the last 25 years, several studies have reported environmental concentrations of PCBs both in biotic and abiotic compartments (Colombo et al., 1990, 1995, 2005, 2007b, 2011; Ondarza et al., 2014; Cappelletti et al., 2014; Torres et al., 2015), including a peak discharge in the Río de la Plata estuary in 2001-2002 evidenced by a threefold increase of muscle concentrations in a detritivorous fish coinciding with PCB banning in 2002 (Colombo et al., 2007a). Nevertheless, air data from Argentina are scarce and limited to a local area in the southern Buenos Aires Province monitored for two periods showing higher PCB levels at urban sites relative to agricultural areas (Tombesi et al., 2014).

The purpose of this study was to more comprehensively evaluate atmospheric PCB patterns in the most productive and populated area of Argentina. We performed an exhaustive regional scale assessment focused on the evaluation of the sources, spatial variability and compositional patterns of airborne PCBs in areas with contrasted land uses and urbanization.

\section{Materials and methods}

\subsection{Study area}

The Southern Rio de la Plata basin comprised by Argentinean provinces of Entre Rios and Buenos Aires and the Autonomous City of Buenos Aires (CABA), is the most populated area of the country concentrating 19.7 million people (49\% of total country; INDEC, 2010). It also presents a great economic significance due to important port activity exporting

Table 1

Sampling site information and atmospheric PCBs concentrations in the Southern Río de la Plata Basin.

\begin{tabular}{|c|c|c|c|c|c|}
\hline \multirow[t]{2}{*}{ Sampling sites, acronyms } & \multirow[t]{2}{*}{ Latitude/longitude } & \multirow[t]{2}{*}{ Population } & \multirow[t]{2}{*}{ Classification } & \multicolumn{2}{|c|}{$\sum \mathrm{PCB}\left(\mathrm{pg} \mathrm{m}^{-3}\right)$} \\
\hline & & & & Range & $\operatorname{Avg} \pm s d$ \\
\hline \multicolumn{6}{|l|}{ Entre Rios Province } \\
\hline La Paz, LPZ & $30^{\circ} 43^{\prime} 35.5^{\prime \prime} \mathrm{S} / 59^{\circ} 38^{\prime} 5.5^{\prime \prime} \mathrm{W}$ & 28000 & Urban (small) & $5-32$ & $15 \pm 10$ \\
\hline Concordia, CON & $31^{\circ} 21^{\prime} 59.3^{\prime \prime} \mathrm{S} / 57^{\circ} 59^{\prime} 41.6^{\prime \prime} \mathrm{W}$ & 170033 & Urban (medium) & $4-81$ & $32 \pm 27$ \\
\hline Paraná, PAR & $31^{\circ} 42^{\prime} 20.5^{\prime \prime} \mathrm{S} / 60^{\circ} 33^{\prime} 37.8^{\prime \prime} \mathrm{W}$ & 339930 & Urban (medium) & $20-115$ & $70 \pm 37$ \\
\hline Villaguay, VGY & $31^{\circ} 54^{\prime} 46.8^{\prime \prime} \mathrm{S} / 59^{\circ} 5^{\prime} 55.4^{\prime \prime} \mathrm{W}$ & $<100$ & Rural & b.d.l.-8 & $3 \pm 4$ \\
\hline Victoria, VIC & $32^{\circ} 37^{\prime} 47.9^{\prime \prime} \mathrm{S} / 60^{\circ} 10^{\prime} 6.4^{\prime \prime} \mathrm{W}$ & 35767 & Urban (small) & $9-309$ & $99 \pm 117$ \\
\hline Gualeguaychú, GUA & $33^{\circ} 4^{\prime} 0.53^{\prime \prime} \mathrm{S} / 58^{\circ} 23^{\prime} 24.9^{\prime \prime} \mathrm{W}$ & $<100$ & Rural & $7-35$ & $23 \pm 13$ \\
\hline \multicolumn{6}{|l|}{ Buenos Aires Province } \\
\hline San Nicolás, SN & $33^{\circ} 22^{\prime} 29.1^{\prime \prime} \mathrm{S} / 60^{\circ} 10^{\prime} 19.0^{\prime \prime} \mathrm{W}$ & 145857 & Urban (medium) & $73-284$ & $146 \pm 68$ \\
\hline Pergamino, PER & $33^{\circ} 54^{\prime} 4.3^{\prime \prime} \mathrm{S} / 60^{\circ} 35^{\prime} 33.3^{\prime \prime} \mathrm{W}$ & 104590 & Urban (medium) & $130-728$ & $364 \pm 261$ \\
\hline Zárate, ZAR & $34^{\circ} 5^{\prime} 31.91^{\prime \prime} \mathrm{S} / 59^{\circ} 1^{\prime} 2.47^{\prime \prime} \mathrm{W}$ & 114269 & Urban (medium) & $41-100$ & $70 \pm 42$ \\
\hline San Antonio de Areco, SAA & $34^{\circ} 14^{\prime} 22.3^{\prime \prime} \mathrm{S} / 59^{\circ} 29^{\prime} 55.9^{\prime \prime} \mathrm{W}$ & 23138 & Urban (small) & $11-110$ & $32 \pm 27$ \\
\hline Inés Indart, INI & $34^{\circ} 24^{\prime} 24.3^{\prime \prime} \mathrm{S} / 60^{\circ} 32^{\prime} 17.9^{\prime \prime} \mathrm{W}$ & 911 & Rural & $2-23$ & $11 \pm 10$ \\
\hline Magdalena, MGD & $35^{\circ} 1^{\prime} 44.6^{\prime \prime} \mathrm{S} / 57^{\circ} 30^{\prime} 27.1^{\prime \prime} \mathrm{W}$ & 19301 & Suburban & $10-70$ & $37 \pm 21$ \\
\hline Punta Indio, PI & $35^{\circ} 16^{\prime} 38.9^{\prime \prime} \mathrm{S} / 57^{\circ} 13^{\prime} 24.5^{\prime \prime} \mathrm{W}$ & 9888 & Suburban & $3-35$ & $19 \pm 12$ \\
\hline Saladillo, SAL 1 & $35^{\circ} 38^{\prime} 13.3^{\prime \prime} \mathrm{S} / 59^{\circ} 47^{\prime} 28.77^{\prime \prime} \mathrm{W}$ & 23313 & Urban (small) & $15-25$ & $20 \pm 7$ \\
\hline SAL 2 & $35^{\circ} 36^{\prime} 30.5^{\prime \prime} \mathrm{S} / 59^{\circ} 50^{\prime} 14.0^{\prime \prime} \mathrm{W}$ & $<100$ & Rural & $1-14$ & $7 \pm 6$ \\
\hline Treinta de Agosto, TR 1 & $36^{0} 11^{\prime} 56.9^{\prime \prime} \mathrm{S} / 62^{\circ} 33^{\prime} 7.7^{\prime \prime} \mathrm{W}$ & 4777 & Suburban & $48-197$ & $128 \pm 56$ \\
\hline TR 2 & $36^{0} 16^{\prime} 38.1^{\prime \prime} \mathrm{S} / 62^{\circ} 32^{\prime} 14.4^{\prime \prime} \mathrm{W}$ & $<100$ & Rural & $6-29$ & $14 \pm 10$ \\
\hline Bolivar, BOL & $36^{\circ} 23^{\prime} 38.2^{\prime \prime} \mathrm{S} / 61^{\circ} 8^{\prime} 30.3^{\prime \prime} \mathrm{W}$ & $<100$ & Rural & b.d.l.-6 & $3 \pm 3$ \\
\hline Rauch, RAU 1 & $36^{\circ} 46^{\prime} 04.8^{\prime \prime} \mathrm{S} / 59^{\circ} 05^{\prime} 33.7^{\prime \prime} \mathrm{W}$ & 15176 & Urban (small) & $11-12$ & $12 \pm 0$ \\
\hline RAU 2 & $36^{\circ} 49^{\prime} 51.8^{\prime \prime} \mathrm{S} / 59^{\circ} 16^{\prime} 43^{\prime \prime} \mathrm{W}$ & $<100$ & Rural & 2 & $2 \pm 0$ \\
\hline Quilmes, QUI & $34^{\circ} 44^{\prime} 18.7^{\prime \prime} \mathrm{S} / 58^{\circ} 12^{\prime} 6.5^{\prime \prime} \mathrm{W}$ & 582943 & Urban (medium) & $49-490$ & $217 \pm 181$ \\
\hline Ensenada, ENS & $34^{\circ} 48^{\prime} 54.4^{\prime \prime} \mathrm{S} / 57^{\circ} 58^{\prime} 31.2^{\prime \prime} \mathrm{W}$ & 8410 & Suburban & $36-146$ & $86 \pm 56$ \\
\hline La Plata, LPT 1 & $34^{\circ} 54^{\prime} 51.9^{\prime \prime} \mathrm{S} / 57^{\circ} 56^{\prime} 40.3^{\prime \prime} \mathrm{W}$ & 654324 & Urban (medium) & $106-409$ & $253 \pm 132$ \\
\hline LPT 2 & $34^{\circ} 53^{\prime} 25.6^{\prime \prime} \mathrm{S} / 57^{\circ} 56^{\prime} 0.9^{\prime \prime} \mathrm{W}$ & 654324 & Urban (medium) & $245-821$ & $509 \pm 291$ \\
\hline LPT 3 & $35^{\circ} 1^{\prime} 4.0^{\prime \prime} \mathrm{S} / 58^{\circ} 2^{\prime} 10.1^{\prime \prime} \mathrm{W}$ & 17872 & Urban (small) & $27-130$ & $63 \pm 41$ \\
\hline La Balandra, BLD & $34^{\circ} 55^{\prime} 45.8^{\prime \prime} \mathrm{S} / 57^{\circ} 43^{\prime} 1.9^{\prime \prime} \mathrm{W}$ & 2729 & Suburban & $6-99$ & $53 \pm 36$ \\
\hline Florencio Varela, VAR & $34^{\circ} 50^{\prime} 24.6^{\prime \prime} \mathrm{S} / 58^{\circ} 14^{\prime} 31.1^{\prime \prime} \mathrm{W}$ & 426005 & Urban (medium) & $59-321$ & $190 \pm 185$ \\
\hline \multicolumn{6}{|l|}{ Buenos Aires City } \\
\hline CABA 1 & $34^{\circ} 37^{\prime} 26.4^{\prime \prime} \mathrm{S} / 58^{\circ} 24^{\prime} 1.4^{\prime \prime} \mathrm{W}$ & 2890151 & Urban (large) & 209-937 & $478 \pm 318$ \\
\hline CABA 2 & $34^{\circ} 37^{\prime} 10.8^{\prime \prime} \mathrm{S} / 58^{\circ} 21^{\prime} 26.7^{\prime \prime} \mathrm{W}$ & 2890151 & Urban (large) & $183-514$ & $287 \pm 128$ \\
\hline
\end{tabular}

b.d.l.: Below detection limit. 
manufacture products (i.e. vehicles, textiles, chemicals, petrochemicals, and steel) and agricultural commodities. Furthermore, it is the prime agricultural land in Argentina (Merini et al., 2007) producing 40-70\% of the cereal and legume crops ( $\approx 100$ millions of tonnes; NMACF, 2014).

\subsection{Air sampling}

Passive Air Samplers (PUF-PAS) consisting of a polyurethane disk ( $14 \mathrm{~cm}$ diameter; $1.5 \mathrm{~cm}$ thick; $385 \mathrm{~cm}^{2}$ surface area; $0.03 \mathrm{~g} \mathrm{~cm}^{-3}$ density) housed in two stainless steel dome chambers (external diameters: 24.5 and $22.5 \mathrm{~cm}$ ) were deployed at twenty-nine sites covering an area of $>400,000 \mathrm{~km}^{2}\left(30^{\circ} 43^{\prime}-36^{\circ} 46^{\prime} \mathrm{S}\right.$ and $\left.57^{\circ} 13^{\prime}-62^{\circ} 33^{\prime} \mathrm{W}\right)$ from July 2010 to December 2014. PUF-PAS were placed 3-4 m above the ground on street lights or trees on public or private lands (yacht clubs, fishing/ sport clubs, private houses/farms). Individual deployments (2 to 12 depending on the stations) lasted for $\approx 4$ months each (mean period span: 133 days, total sample $\mathrm{N}^{\circ}=141$ ).

Sampling locations were classified according to population into rural ( $<1000$ inhabitants), suburban (1000-10,000 inhabitants) and urban sites with a further sub-division into small $(10,000-100,000)$; medium (100,000-1 million) and large cities (>1 million inhabitants; Table 1).

Prior to each campaign, sampling chambers were prewashed, solvent-rinsed (acetone and petroleum ether), and stored in polyethylene bags. Pre-cleaned PUF disks (distilled water wash and 1:1 $\mathrm{v} / \mathrm{v}$ acetone:petroleum ether Soxhlet extraction for $24 \mathrm{~h}$ ) were fortified with 10 ng of Depuration Compounds (PCB 30, 119 and 207; Absolute Standard Inc.) to assess site-specific sampling rates $\left(R ; \mathrm{m}^{3} \mathrm{~d}^{-1}\right)$ according to Astoviza et al. (2016) and individually stored at $-10{ }^{\circ} \mathrm{C}$ until deployment.

\subsection{Chemical analysis}

After exposition PUF disks were wrapped in aluminium foil, labelled, placed into ziplock polyethylene bags and transported in a cooler to the laboratory where they were stored frozen until analysis. Field blanks $(n=15)$ were obtained by transporting, installing and immediately removing PUF disks during each deployment.

Samples were spiked with internal standards (PCB 103 and 198) and Soxhlet extracted with petroleum ether $24 \mathrm{~h}$. Extract clean-up was performed on silica gel columns (SamplingQ Agilent) eluted with petroleum ether and concentrated to $500 \mu \mathrm{l}$ under a gentle stream of dry nitrogen. In this study, 42 congeners (di-CBs: $8 / 5$; tri-CBs: $16 / 32,17$, 18, 31/28, 33/20; tetra-CBs: 41, 44, 49, 52, 70, 74; penta-CBs: 82,87 / 115, 95/66, 99, 101, 110/77, 118; hexa-CBs: 128/167, 132/105, 138, 141, 149/123, 151, 153, 158, 171/156, 187; hepta-CBs: 170, 174, 177, 180, 183, 191; octa-CBs: 194, 195/208, 199, 203/196, 205; nona-CBs: 206; deca-CBs: 209) were analyzed by HRGC-ECD (Agilent 6890, Agilent Tech., USA) equipped with a DB5 capillary column (30 m $\times 320 \mu \mathrm{m}$ i. d. $\times 0.25 \mu \mathrm{m}$ film thickness). The working conditions were: injector temperature $250{ }^{\circ} \mathrm{C}$, detector temperature $330{ }^{\circ} \mathrm{C}$; oven temperature program $65{ }^{\circ} \mathrm{C}(2 \mathrm{~min}), 10{ }^{\circ} \mathrm{C} \mathrm{min}-1$ to $130^{\circ} \mathrm{C}(1 \mathrm{~min}), 5^{\circ} \mathrm{C} \mathrm{min}^{-1}$ to $300{ }^{\circ} \mathrm{C}(10 \mathrm{~min})$ and carrier gas Nitrogen (purity $>99.99 \%$ ) at $1.5 \mathrm{ml} \mathrm{min}^{-1}$. Quantification was performed by a four-point calibration curve using external standard solutions (2, 10, 50, 250 pg/ul; Quebec Ministry, AccuStandard Inc.).

\subsection{Quality assurance/quality control ( $Q A / Q C)$}

Method detection limits (MDL: 131-1621 pg PUF ${ }^{-1}$, Table S1) were defined as the average of field $(n=15)$ and laboratory blanks $(n=8)$ plus three standard deviations. For non-detected compounds, one half of the instrumental detection limit (IDL: equivalent amount of the signal-to-noise ratio $\geq 3$ ) was used as MDL. Recovery efficiency averaged $74 \pm 29 \%$ for PCB 103 and $70 \pm 32 \%$ for PCB 198; correction was applied when sample recovery was below $85 \%$.

\subsection{Deriving air concentrations from depuration compounds}

Site specific sampling rates $(R)$ and air concentrations of each PCB congener were calculated based on the loss of DCs, the average ambient temperature for each sampling period and site, and congener specific effective air volumes $\left(\mathrm{V}_{\mathrm{ef}}\right)$ according to previously described methods (Astoviza et al., 2016). The average $R$ value for the entire study (6.3 \pm $3.6 \mathrm{~m}^{3}$ day $^{-1}$ ) is comparable to other PAS-PUF reports around the globe, i.e. $4.8 \pm 2.3 \mathrm{~m}^{3}$ day $^{-1}$ (Pozo et al., 2004), $5.9 \pm 0.9 \mathrm{~m}^{3}$ day $^{-1}$ (Gouin et al., 2008) and $6.1 \pm 1.8 \mathrm{~m}^{3}$ day $^{-1}$ (Persoon and Hornbuckle, 2009).

\subsection{Statistical analyses}

Statistical analyses were performed with XLSTAT 2014 software package (Addinsoft, 2014); ANOVA tests were used to compare differences between sampling areas (significance level set at $\mathrm{p}<0.05$ ) and regression analysis was used to evaluate covariation of population and $\sum$ PCBs air concentrations. Spatial and compositional patterns compared to different source profiles (e.g. Aroclor mixtures, combustion sources and potential emission sources such as electrical equipment and building supplies, Frame et al., 1996; Conolly, 2001; Ishikawa et al., 2007) were further evaluated by principal component analysis (PCA) based on 36 standardized PCB congener concentrations which were present in $>40 \%$ of samples. PCA facilitates the interpretation of complex, multivariate data by transforming the original set of variables into a smaller set of linear combinations preserving the greatest amount of information or variance (Wannaz et al., 2013). Original variables

Table 2

Atmospheric concentration of PCBs (in $\mathrm{pg} \mathrm{m}^{-3}$ ) from diverse PAS-PUF sampling programs.

\begin{tabular}{|c|c|c|c|c|c|}
\hline \multirow[t]{2}{*}{ Region } & \multirow[t]{2}{*}{ Congeners } & \multirow{2}{*}{$\begin{array}{l}\text { Sites } \\
(\mathrm{N})\end{array}$} & \multicolumn{2}{|c|}{$\Sigma$ PCBs $\left(\mathrm{pg} \mathrm{m}^{-3}\right)$} & \multirow[t]{2}{*}{ References } \\
\hline & & & Range & Average & \\
\hline \multicolumn{6}{|l|}{ Urban } \\
\hline Italy & $\Sigma 21$ & $6(6)$ & $14-270$ & 117 & $\begin{array}{l}\text { Estellano et al., } \\
2012\end{array}$ \\
\hline Spain & $\Sigma 48$ & $1(4)$ & $33-259$ & 122 & Pozo et al., 2009 \\
\hline Argentina & $\Sigma 42$ & $\begin{array}{l}15 \\
(64)\end{array}$ & $2-937$ & 146 & This study \\
\hline Chile & $\Sigma 48$ & $6(6)$ & $40-350$ & 160 & Pozo et al., 2012 \\
\hline $\begin{array}{l}\text { Argentina (Bahia } \\
\text { Blanca) }\end{array}$ & $\Sigma 48$ & $3(6)$ & $40-360$ & 200 & $\begin{array}{l}\text { Tombesi et al., } \\
2014\end{array}$ \\
\hline India & $\Sigma 48$ & $1(8)$ & $133-390$ & 278 & Pozo et al., 2011 \\
\hline Canada & $\Sigma 13$ & $\begin{array}{l}3 \\
(10)\end{array}$ & $102-1346$ & 481 & $\begin{array}{l}\text { Motelay-Massei et } \\
\text { al., } 2005\end{array}$ \\
\hline Europe & $\Sigma 29$ & $\begin{array}{l}23 \\
(23)\end{array}$ & $76-1924$ & 719 & Jaward et al., 2004 \\
\hline France & $\Sigma 48$ & $1(3)$ & $2401-4052$ & 3097 & Pozo et al., 2009 \\
\hline \multicolumn{6}{|l|}{ Suburban/semirural } \\
\hline Argentina & $\Sigma 42$ & $\begin{array}{l}3 \\
(13)\end{array}$ & $3-146$ & 48 & This study \\
\hline Canada & $\Sigma 13$ & $2(5)$ & $67-129$ & 96 & $\begin{array}{l}\text { Motelay-Massei et } \\
\text { al., } 2005\end{array}$ \\
\hline Korea & $\Sigma 142$ & $2(2)$ & $94-222$ & 158 & Hogarh et al., 2012 \\
\hline Japan & $\Sigma 142$ & $4(4)$ & $59-696$ & 291 & Hogarh et al., 2012 \\
\hline Taiwan & $\Sigma 142$ & $1(1)$ & & 316 & Hogarh et al., 2012 \\
\hline \multicolumn{6}{|l|}{ Rural } \\
\hline Argentina & $\Sigma 42$ & $\begin{array}{l}7 \\
(31)\end{array}$ & bdl-35 & 10 & This study \\
\hline $\begin{array}{l}\text { Argentina (Bahia } \\
\text { Blanca) }\end{array}$ & $\Sigma 48$ & $\begin{array}{l}5 \\
(10)\end{array}$ & bdl-60 & 20 & $\begin{array}{l}\text { Tombesi et al., } \\
2014\end{array}$ \\
\hline Korea & $\Sigma 142$ & $\begin{array}{l}11 \\
(11)\end{array}$ & $36-288$ & 127 & Hogarh et al., 2012 \\
\hline Canada & $\Sigma 13$ & $1(3)$ & $66-269$ & 152 & $\begin{array}{l}\text { Motelay-Massei et } \\
\text { al., } 2005\end{array}$ \\
\hline Japan & $\Sigma 142$ & $\begin{array}{l}37 \\
(37)\end{array}$ & $41-7279$ & 322 & Hogarh et al., 2012 \\
\hline China & $\Sigma 142$ & $1(1)$ & & 1034 & Hogarh et al., 2012 \\
\hline
\end{tabular}


which are positively correlated plot together whereas negatively associated variables oppose in the PCA; their similarity is described by the Euclidean distance (Blanchard et al., 2006).

\section{Results and discussion}

Airborne concentrations of $\sum_{42} \mathrm{PCBs}$ at each sampling site are summarized in Table 1, and compared to other passive air monitoring programs in Table 2. Detailed information for each sampling period is included in Supplementary material (Table S1).

Broadly, PCB levels in air of the Southern Río de la Plata Basin are largely variable (below detection limit to $937 \mathrm{pg} \mathrm{m}^{-3}$; mean $106 \pm$ $160 \mathrm{pg} \mathrm{m}^{-3}$ ) and correspond to a low/very low range compared to values reported for the First Year of the Global Atmospheric Passive Sampling Programme (GAP: $332 \mathrm{pg} \mathrm{m}^{-3}$; Pozo et al., 2009) and for Latin America and Caribbean countries (296 pg m${ }^{-3}$; Bogdal et al., 2013). Significant differences $(\mathrm{p}<0.001$ ) are found between sampling sites according to population with a decreasing pattern from urban

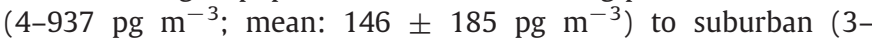
$146 \mathrm{pg} \mathrm{m}^{-3}$; mean: $48 \pm 41 \mathrm{pg} \mathrm{m}^{-3}$ ) and rural sites (below detection limit-35 $\mathrm{pg} \mathrm{m}^{-3} ; 10 \pm 10 \mathrm{pg} \mathrm{m}^{-3}$ ). In general, our data are comparable to previous reports from Southern Buenos Aires Province (40$360 \mathrm{pg} \mathrm{m}^{-3}$; Tombesi et al., 2014) and from neighbouring countries such as Chile (40-350 $\mathrm{pg} \mathrm{m}^{-3}$; Pozo et al., 2012), and Brazil (70$620 \mathrm{pg} \mathrm{m}^{-3}$; Ornellas-Meire et al., 2012) but are consistently lower than data reported for Europe, Asia and North America and an order of magnitude lower than global urban sites (Li et al., 2010). The lower airborne PCB profile of South American countries reflects their lower utilization compared to the Northern Hemisphere which concentrates almost 97\% of the global historical use of PCBs (Breivik et al., 2002).

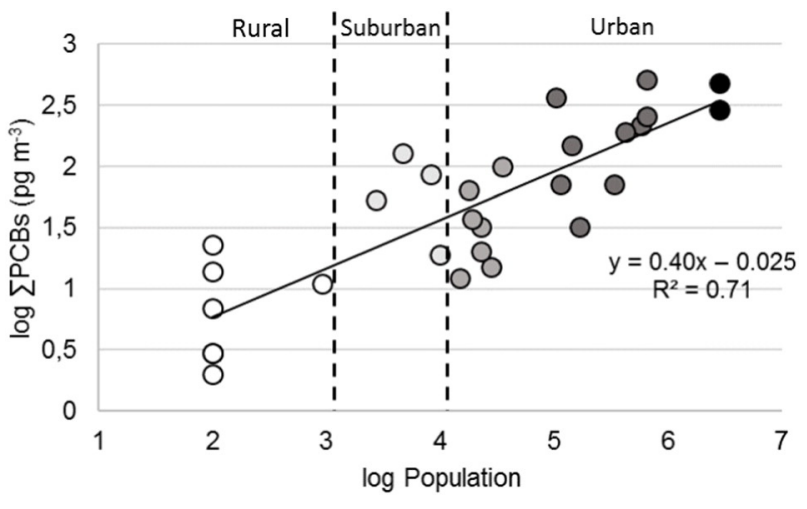

Fig. 2. Airborne $\log \sum \mathrm{PCB}$ concentrations vs. $\log$ population at each sampling site. The population class is indicated by the point colors (white: rural; light gray: suburban; medium gray: urban-small; dark gray: urban-medium; black: urban-large).

\subsection{Spatial variability}

Airborne PCB concentrations are mapped in Fig. 1. Briefly, higher concentrations correspond to urban sites of Great Buenos Aires metropolitan area (CABA, LPT, QUI and VAR; mean: 478; 287; 253; 509; 217 and $190 \mathrm{pg} \mathrm{m}^{-3}$, respectively) and the North of Buenos Aires Province (PER and SN: 364 and $146 \mathrm{pg} \mathrm{m}^{-3}$, respectively). All of these locations are urban with populations $>100,000$ inhabitants and/or industrial sites such as San Nicolas which host the largest steelmaking plant of the country with its own thermal power plant.

In contrast, rural sites from central Entre Rios and central-south of Buenos Aires (VGY, SAL, BOL and RAU) show the lowest concentrations (mean: $3 ; 7 ; 3$ and $2 \mathrm{pg} \mathrm{m}^{-3}$, respectively), reflecting a baseline level for

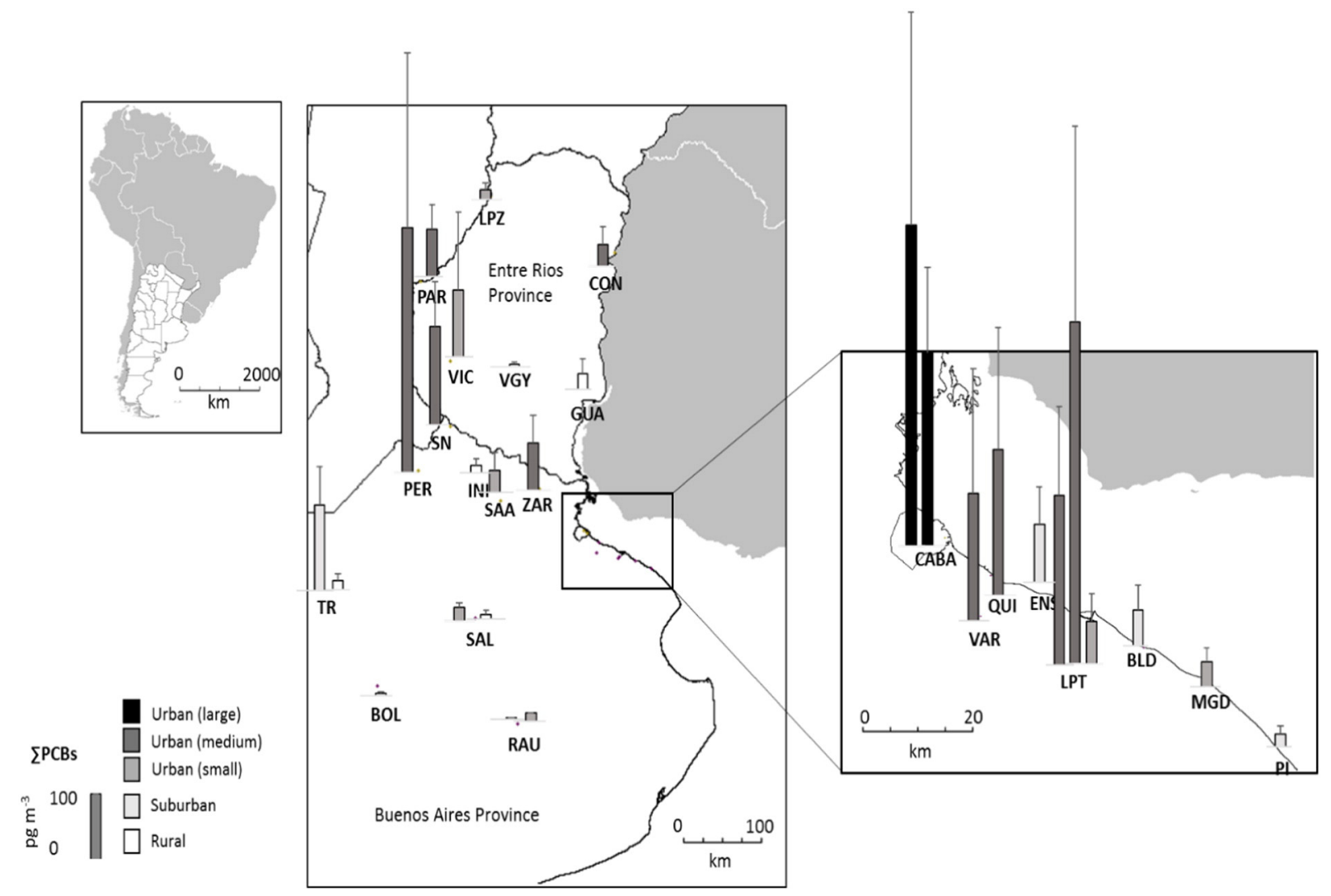

Fig. 1. Spatial distribution of atmospheric PCBs in the Southern Río de la Plata Basin. 
the whole area, whereas suburban concentrations (PI, BLD and ENS; mean: 19; 53 and $86 \mathrm{pg} \mathrm{m}^{-3}$, respectively) are intermediate.

Rural-urban increasing patterns for atmospheric PCB have been described for other world areas (e.g. Great Lakes, Canada; Motelay-Massei et al., 2005; Sun et al., 2007). The significant positive potential correlation $\left(\mathrm{p}<0.001 ; \mathrm{R}^{2}: 0.72\right)$ between $\log$ concentration and log population size (Fig. 2) confirms the role of urbanization scale as the primary driving force of atmospheric pollution in the Southern Río de la Plata Basin. Similar potential slopes have been reported for different organic compounds (PAHs: 0.5-0.6, Hafner et al., 2005; PBDEs: 0.3, Venier et al., 2009; PCDD/Fs: 0.28-0.35, Cappelletti et al., 2015) and inorganic pollutants (nitrogen dioxide: 0.5; Lamsal et al., 2013). According to Bettencourt et al. (2007), scaling exponents for urban indicators vs. city size lower than 1 correspond to infrastructure (e.g. length of electrical networks, road surfaces). In addition to the higher PCB contribution from larger electric networks and buildings with aged paints, the increased heat and reduced air circulation in big cities could have a synergistic effect amplifying atmospheric concentrations, i.e. enhanced volatilization due to heat island effect (Camilloni and Barros, 1997) and/or lower dispersion due to the 'street canyon effect' (Radojević and Bashkin, 1999).

\subsection{Compositional patterns}

The general atmospheric profile in Southern Rio de la Plata basin is dominated by intermediate volatility PCBs ( $\log$ Koa: 7.5-10.7), namely penta-CBs $(38 \pm 14 \%)$ followed by hexa-CBs $(23 \pm 10 \%)$ and tri and tetra-CBs ( $18 \pm 13 \%$ and $16 \pm 7 \%$, respectively) with minimum proportions of di, hepta to deca-CBs. However, there are some compositional differences between sampling sites: urban locations have a relatively
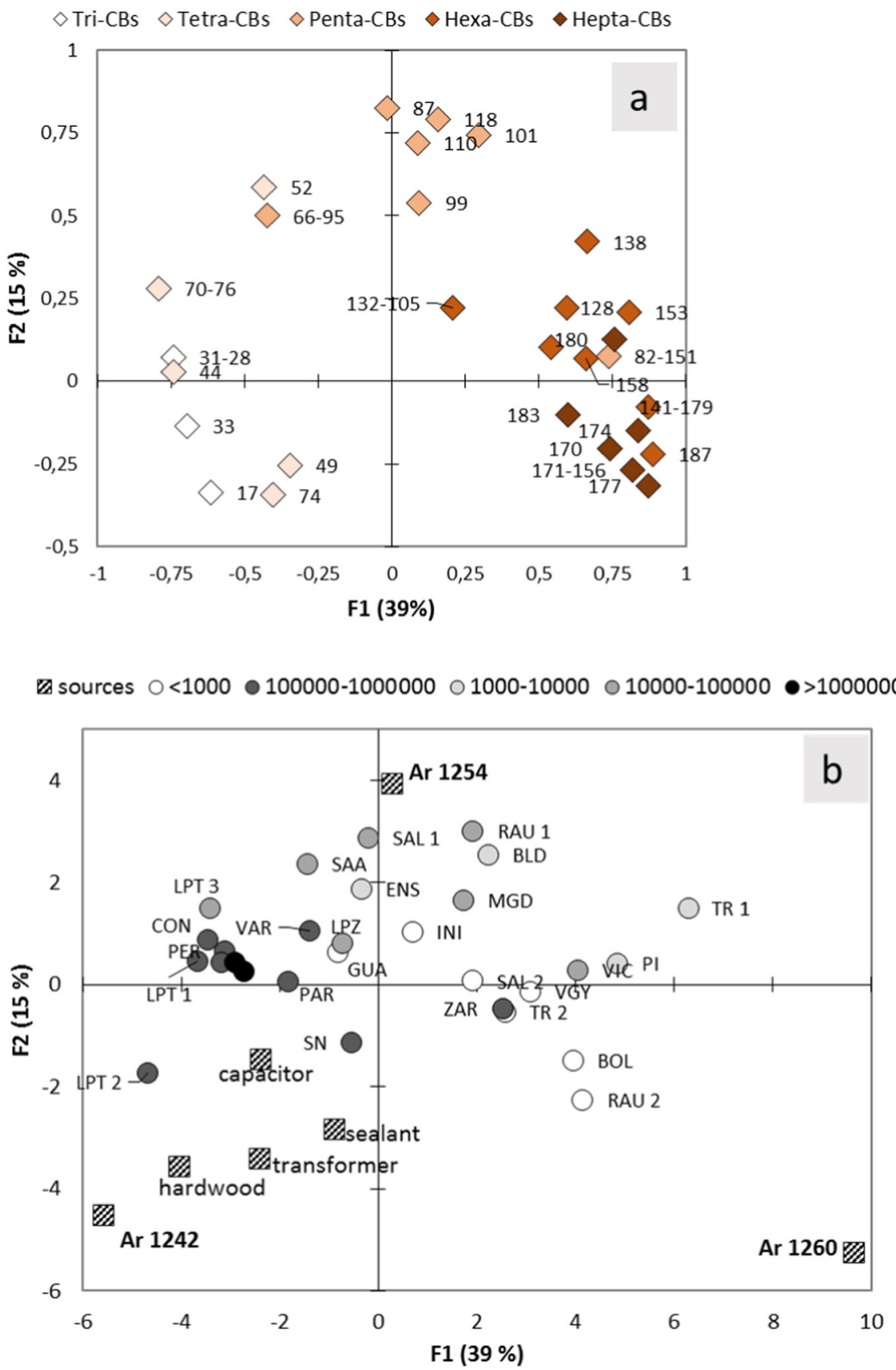

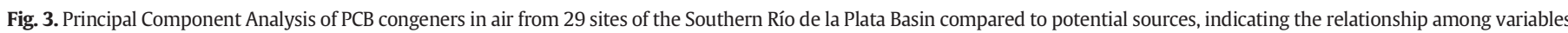
(a) and sites, colored by population, see Fig. 2 (b). 
uniform profile of penta-CBs (33 $\pm 9 \%)$ followed by tri- $(24 \pm 12 \%)$, tetra- (20 $\pm 4 \%)$ and hexa-CBs (19 $\pm 7 \%)$; and reduced hepta-, octato-deca-CBs whereas rural and suburban sites show a heavier pattern enriched in penta- plus hexa-CBs ( $82 \pm 16 \%$ and $69 \pm 8 \%$, respectively) and lower tetra- ( $8 \pm 6 \% ; 14 \pm 7 \%)$, tri- $(6 \pm 9 \% ; 7 \pm 6 \%$ ) and hepta-CBs ( $3 \pm 6 \% ; 7 \pm 3 \%$ ). A similar shift on PCB composition has been reported for urban and rural locations in Europe (Jaward et al., 2004; Fig. S1).

Since there are detailed variations among sites, a principal component analysis (PCA) was performed to further investigate the spatial differences and compare these profiles to different known sources such as Aroclor mixtures (1242, 1254 and 1260; Frame et al., 1996), combustion and potential emission sources (hardwood, sealants, transformers and capacitors; Conolly, 2001). In this study, 70\% of variability of 36 PCB congeners detected in at least $40 \%$ of the samples is explained by 4 components. The first (PC1) and second principal components (PC2) accounted for $39 \%$ and $15 \%$ of the variance, respectively. The relationships among the variables are shown in the loading plot (Fig. 3a), whereas the grouping of the sites colored according to population size (directly related to PCB levels) and potential source are displayed in the score plot (Fig. 3b).

PC1 is basically defined by the opposing contribution of lower more volatile PCBs $(-\mathrm{PC} 1)$ and higher chlorinated PCBs $(+\mathrm{PC} 1)$ whereas PC2 has a positive loading of five PCB congeners (52, 87, 101, 110 and 118). Emission sources and sampling sites spread in a triangular shape limited by Aroclors mixtures, light 1242 together with emission sources at the bottom left $(-\mathrm{PC} 1,-\mathrm{PC} 2)$, intermediate 1254 at the top $(+\mathrm{PC} 2)$ and heavier chlorinated 1260 at the bottom right (+ PC1, - PC2). Most populated large cities with higher PCB concentrations enriched in less chlorinated congeners plot to the left $(-\mathrm{PC} 1)$ near to lighter Aroclor mixtures and emission sources; suburban and small urban sites related to intermediate-chlorinated Aroclor 1254 occupy the central-upper part ( + PC2) and rural sites with background PCB levels dominated by heavier homologues progressively shift to the bottom-right (+ PC1, - PC2; Fig. 3b) closer to Aroclor 1260. In fact, our airborne PCB profiles seem to result basically from the combination of Aroclors 1242-1254 in most polluted, large urban sites, and from the gradual shift from 1254 to 1260 in small urban to rural sites.

This pattern of heavier Aroclor predominance in rural sites does not match the expected profile of lighter PCBs prevailing in remote areas due to their increased transport capacity (Wania and Mackay, 1996) or the prevalence of intermediate-chlorinated congeners with longer half-lives and lower Koa than heavier homologues which are more efficiently removed by particle-bond deposition (Shen et al., 2006). Actually, intermediate chlorinated congeners remain in the atmosphere long enough to undergo long-range transport as has been reported in air from Chile (Pozo et al., 2004; Shunthirasingham et al., 2011), and China (Jaward et al., 2004; Hogarh et al., 2012).

The predominance of heavier compounds in rural samples of the southern Rio de la Plata Basin is also reflected by the tri + tetra/hexa CB ratio $(31-28+49 / 153+138)$ that seems a good descriptor of the observed compositional variability and is significantly correlated both with total PCB atmospheric concentrations $\left(\mathrm{R}^{2}: 0.39\right)$ and urban scale $\left(\mathrm{R}^{2}: 0.35\right)$. This compositional pattern of rural sites probably reflects the long range transport of more persistent congeners and their diffusive input from historical reservoirs (e.g. soils) corresponding to an aged signal. The lighter profiles in large urban centers are probably related to the continuous release of PCBs from electrical equipment (transformers and capacitors), combustion and building supplies (e.g. sealants) with a fresher signature.

\section{Conclusions}

This first comprehensive regional scale assessment of airborne PCBs in the Southern Río de la Plata basin revealed that concentrations range in a low/very low global level, with a strong spatial variability related to a significant rural-urban increasing trend confirming the driving role of urbanization scale in atmospheric pollution. The increasing rural-urban concentration pattern is accompanied by a compositional shift from heavier to lighter PCB predominance reflecting the transition from an aged, background signal at rural sites to a fresher urban trace, indicated by the predominance of combustion and emission sources (electrical and building supplies) and lighter Aroclor mixtures (1242). The tri + tetra/hexa CB ratio adequately describes this compositional shift.

\section{Acknowledgements}

The authors thank the Argentinean Research Council (CONICET) and the National University of La Plata for the financial support.

\section{Appendix A. Supplementary data}

Supplementary data to this article can be found online at http://dx. doi.org/10.1016/j.scitotenv.2016.07.101.

\section{References}

Astoviza, M.J., Cappelletti, N.E., Bilos, C., Migoya, M.C., Colombo, J.C., 2016. Massive airborne Endosulfan inputs related to intensive agriculture in Argentina's Pampa. Chemosphere 144, 1459-1466.

ATSDR, Agency for Toxic Substances and Disease Registry, 2002. Toxicological Profile for Polychlorinated Biphenyls (PCBs).U.S. Department of Health and Human Services. Public Health Service. Agency for Toxic Substances and Disease Registry.

Bettencourt, L.M.A., Lobo, J., Helbing D., Kuhnert, C., West, G.B., 2007. Growth, innovation, scaling, and the pace of life in cities. PNAS 104, 7301-7306.

Blanchard, M., Teil, M.J., Chevreuil, M., 2006. The seasonal fate of PCBs in ambient air and atmospheric deposition in Northern France. J. Atmos. Chem. 53, 123-144.

Bogdal, C. Scheringer, M., Abad, E. Abalos, M., Van Bavel, B. Hagberg, J., Fiedler, H., 2013. Worldwide distribution of persistent organic pollutants in air, including results of air monitoring by passive air sampling in five continents. TrAC, Trends Anal. Chem. 46, 150-161.

Breivik, K., Sweetman, A., Pacyna, J.M., Jones, K.C., 2002. Towards a global historical emission inventory for selected PCB congeners - a mass balance approach 1. Global production and consumption. Sci. Total Environ. 290, 181-198.

Breivik, K., Sweetman, A., Pacyna, J.M., Jones, K.C., 2007. Towards a global historical emission inventory for selected PCB congeners - a mass balance approach 3. An update. Sci. Total Environ. 377, 296-307.

Camilloni, I., Barros, V., 1997. On the urban heat island effect on temperature trends. Climate Change 37, 665-681.

Cappelletti, N.E., Astoviza, M.J., Migoya, M.C., Colombo, J.C., 2015. Airborne PCDD/F profiles in rural and urban areas of Buenos Aires province, Argentina. Organohalogen Compd. 77, 194-197.

Cappelletti, N.E., Skorupka, C.N., Migoya, M.C., Tatone, L.M., Astoviza, M.J., Colombo, J.C., 2014. Behavior of dioxin like PCBs and PBDEs during early diagenesis of organic matter in settling material and bottom sediments from the sewage impacted Buenos Aires' coastal area, Argentina. Bull. Environ. Contam. Toxicol. 93, 388-392.

Colombo, J.C., Cappelletti, N., Migoya, M.C., Speranza, E., 2007a. Bioaccumulation of anthropogenic contaminants by detritivorous fish in the Rio de la Plata Estuary: 2Polychlorinated biphenyls. Chemosphere 69, 1253-1260.

Colombo, J.C., Cappelletti, N., Speranza, E., Migoya, M.C., Lasci, M.J., Skorupka, N., 2007b. Vertical fluxes and organic composition of settling material from the sewage impacted Buenos Aires coastal area, Argentina. Org. Geochem. 38, 1941-1952.

Colombo, A., Benfenati, E., Bugatti, S.G., Lodi, M., Mariani, A., Musmeci, L., Rotella, R., Senese, V., Ziemacki, G., Fanelli, R., 2013. PCDD/Fs and PCBs in ambient air in a highly industrialized city in Northern Italy. Chemosphere 90, 2352-2357.

Colombo, J.C., Bilos, C., Campanaro, M., Presa, M.J.R., Catoggio, J.A., 1995. Bioaccumulation of polychlorinated biphenyls and chlorinated pesticides by the Asiatic Clam Corbicula fluminea: its use as sentinel organism in the Río de la Plata estuary, Argentina. Environ. Sci. Technol. 29, 914-927.

Colombo, J.C., Cappelletti, N., Barreda, A., Migoya, M.C., Skorupka, C., 2005. Vertical fluxes and accumulation of PCBs in coastal sediments of the Río de la Plata estuary, Argentina. Chemosphere 61, 1345-1357.

Colombo, J.C. Cappelletti, N., Williamson, M., Migoya, M.C., Speranza, E., Sericano, J., Muir, D.C.G., 2011. Risk ranking of multiple-POPs in detritivorous fish from the Río de la Plata. Chemosphere 83, 882-889.

Colombo, J.C., Khalil, M.F., Arnac, M., Horth, A.C., Catoggio, J.A., 1990. Distribution of chlorinated pesticides and individual polychlorinated biphenyls in biotic and abiotic compartments of the Río de la Plata, Argentina. Environ. Sci. Technol. 24, 498-505.

Conolly, C., 2001. Speciation of the UK Polychlorinated Biphenyl Emission Inventory, AEAT/r/env/0001.

Dobson, S., van Esch, G.J., 1993. Polychlorinated Biphenyls and Terphenyls, Environmental Health Criteria 140. 2d ed. World Health Organization, International Programme on Chemical Safety (IPCS), Geneva, Switzerland, p. 1993.

Estellano, V.H., Pozo, K., Harner, T., Carsolini, S., Focardi, S., 2012. Using PUF disk passive samplers to simultaneously measure air concentrations of persistent organic pollutants (POPs) across the Tuscany Region, Italy. Atmospheric Pollution Research 3, $88-94$. 
Frame, G.M., Cochran, J.W., Bøwadt, S.S., 1996. Complete PCB congener distributions for 17 Aroclor mixtures determined by 3 HRGC systems optimized for comprehensive, quantitative, congener specific analysis. J. High Resolut. Chromatogr. 19, 657-668.

Gouin, T., Wania, F., Ruepert, C., Castillo, L.E., 2008. Field testing passive air samplers for current use pesticides in a tropical environment. Environ. Sci. Technol. 42. 6625-6630.

Gregoris, E., Argiriadis, E., Vecchiato, M., Zambon, S., De Pieri, S., Donateo, A., Contini, D., Piazza, R., Barbante, C., Gambaro, A., 2014. Gas-particle distributions, sources and health effects of polycyclic aromatic hydrocarbons (PAHs), polychlorinated biphenyls (PCBs) and polychlorinated naphthalenes (PCNs) in Venice aerosols. Sci. Total Environ. 476-477, 393-405.

Hafner, W., Carlson, D., Hites, R.A., 2005. Influence of local human population on atmospheric polycyclic aromatic hydrocarbon concentrations. Environ. Sci. Technol. 39, 7374-7379.

Halsall, C.J., Lee, R.G.M., Coleman, P.J., Burnett, V., Harding-Jones, P., Jones, K.C., 1995. PCBs in U. K. Urban Air. Environ. Sci. Technol. 29, 2368-2376.

Harner, T., Shoeib, M., Diamond, M., Stern, G., Rosenberg, B., 2004. Using passive air samplers to assess urban-rural trends for persistent organic pollutants. 1. Polychlorinated biphenyls and organochlorine pesticides. Environ. Sci. Technol. 38, 4474-4483.

Hogarh, J.N., Seike, N., Kobara, Y., Habib, A., Namd, J.J., Lee, J.S., Li, Q., Liu, X., Li, J., Zhang, G., Masunaga, S., 2012. Passive air monitoring of PCBs and PCNs across East Asia: a comprehensive congener evaluation for source characterization. Chemosphere 86, $718-726$.

INDEC, (National Institute of Statistics and Census of Argentina), 2010. National Census. (accessed in July 2014) http://www.indec.mecon.ar.

International Agency for Research on Cancer (IARC), 2015. Polychlorinated Biphenyls and Polybrominated Biphenyls. IARC Monographs on the Evaluation of Carcinogenic Risks to Humans. 107.

Ishikawa, Y., Noma, Y., Mori, Y., Sakai, S., 2007. Congener profiles of PCB and a proposed new set of indicator congeners. Chemosphere 67, 1838-1851.

Jaward, F.M., Farrar, N.J., Harner, T., Sweetman, A., Jones, K.C., 2004. Passive air sampling of PCBs, PBDEs, and organochlorine pesticides across Europe. Environ. Sci. Technol. 38, 34-41.

Lamsal, L.N., Martin, R.V., Parrish, D.D., Krotkov, N.A., 2013. Scaling relationship for $\mathrm{NO}_{2}$ pollution and urban population size: a satellite perspective. Environ. Sci. Technol. 47, 7855-7861.

Li, Y.-F., Harner, T., Liu, L., Zhang, Z., Ren, N.-Q., Jia, H., Ma, J., Sverko, E., 2010. Polychlorinated biphenyls in global air and surface soil: distributions, air-soil exchange, and fractionation effect. Environ. Sci. Technol. 44, 2784-2790.

Merini, L.J., Cuadrado, V., Flocco, C.G., Giuletti, A.M., 2007. Dissipation of 2, 4-D in soils of the humid Pampa region, Argentina: a microcosm study. Chemosphere 68, 259-265.

Motelay-Massei, A., Harner, T., Shoeib, M., Diamond, M., Stern, G., Rosenbreg, B., 2005. Using passive air samplers to assess urban-rural trends for persistent organic pollutants and polycyclic aromatic hydrocarbons. 2. Seasonal trends for PAHs, PCBs, and organochlorine pesticides. Environ. Sci. Technol. 39, 5763-5773.

NMACF, 2014. National Ministry of Agriculture, Cattle Farming and Fishing. (accessed in November 2014) http://www.siia.gov.ar.

Ondarza, P.M., Gonzalez, M., Fillmann, G., Miglioranza, K.S.B., 2014. PBDEs, PCBs and organochlorine pesticides distribution in edible fish from Negro River basin, Argentinean Patagonia. Chemosphere 94, 135-142.

Ornellas-Meire, R., Lee, S.C., Yao, Y., Targino, A.C., Torres, J.P.M., Harner, T., 2012. Seasonal and altitudinal variations of legacy and current-use pesticides in the Brazilian tropical and subtropical mountains. Atmos. Environ. 59, 108-116.

Park, J.S., Wade, T.L., Sweet, S.T., 2002. Atmospheric deposition of PAHs, PCBs, and organochlorine pesticides to Corpus Christy Bay, Texas. Atmos. Environ. 36, 1707-1720.

Persoon, C., Hornbuckle, K.C., 2009. Calculation of passive sampling rates from both native PCBs and depuration compounds in indoor and outdoor environments. Chemosphere 74, 917-923.
Pozo, K., Harner, T., Lee, S.C., Sinha, R.K., Sengupta, B., Loewen, M., Geethalakshmi, V. Kannan, K., Volpi, V., 2011. Assessing seasonal and spatial trends of persistent organic pollutants (POPs) in Indian agricultural regions using PUF disk passive air samplers. Environ. Pollut. 159, 646-653.

Pozo, K., Harner, T., Lee, S.C., Wania, F., Muir, D.C.G., Jones, K.C., 2009. Seasonally resolved concentrations of persistent organic pollutants in the global atmosphere from the first year of the GAPS study. Environ. Sci. Technol. 43, 796-803.

Pozo, K., Harner, T., Rudolph, A., Oyola, G., Estellano, V.H., Ahumada-Rudolph, R., Garrido, M., Pozo, K., Mabilia, R., Focardi, S., 2012. Survey of persistent organic pollutants (POPs) and polycyclic aromatic hydrocarbons (PAHs) in the atmosphere of rural urban and industrial areas of Concepción, Chile, using passive air samplers. Atmospheric Pollution Research 3, 426-434.

Pozo, K., Harner, T., Shoeib, M., Urrutia, R., Barra, R., Parra, O., Focardi, S., 2004. Passivesampler derived air concentrations of persistent organic pollutants on a northsouth transect in Chile. Environ. Sci. Technol. 38, 6529-6537.

Radojević, M., Bashkin, V.N., 1999. Practical Environmental Analysis. Royal Society of Chemistry (490 pp.).

Shen, L., Wania, F., Lei, Y.D., Teixeira, C., Muir, D.C.G., Xiao, H., 2006. Polychlorinated biphenyls and polybrominated diphenyl ethers in the North American atmosphere. Environ. Pollut. 144, 434-444.

Shunthirasingham, C., Barra, R., Mendoza, G., Montory, M., Oyiliau, C.E., Lei, Y.D., Wania, F., 2011. Spatial variability of atmospheric semivolatile organic compounds in Chile. Atmos. Environ. 45, 303-309.

Sun, P., Basu, I., Blanchard, P., Brice, K.A., Hites, R.A., 2007. Temporal and spatial trends of atmospheric polychlorinated biphenyl concentrations near the Great Lakes. Environ. Sci. Technol. 41, 1131-1136.

Tombesi, N., Pozo, K., Harner, T., 2014. Persistent organic pollutants (POPs) in the atmosphere of agricultural and urban areas in the Province of Buenos Aires in Argentina using PUF disk passive air samplers. Atmospheric Pollution Research 5, 170-178.

Torres, P., Miglioranza, K.S.B., Uhart, M.M., Gonzalez, M., Commendatore, M., 2015. Organochlorine pesticides and PCBs in Southern Right Whales (Eubalaena australis) breeding at Península Valdés, Argentina. Sci. Total Environ. 518-519, 605-615.

UNEP, 1999. Guidelines for the Identification of PCBs and Materials Containing PCBs. UNEP/IOMC August 1999, Geneva, Switzerland.

Van den Berg, M., Birnbaum, L.S., Denison, M., De Vito, M., Farland, W., Feeley, M., Fiedler H., Hakansson, H., Hanberg, A., Haws, L., Rose, M., Safe, S., Schrenk, D., Tohyama, C., Tritscher, A., Tuomisto, J., Tysklind, M., Walker, N., Peterson, R.E., 2006. The 2005 World Health Organization reevaluation of human and mammalian toxic equivalency factors for dioxins and dioxin-like compounds. Toxicol. Sci. 93, 223-241.

Venier, M., Ferrario, J., Hites, R.A., 2009. Polychlorinated Dibenzo-P-Dioxins and Dibenzofurans in the atmosphere around the Great Lakes. Environ. Sci. Technol. 43 (4), 1036-1041.

Villavert, L, Nadal, M., Schuhmacher, M., Domingo, J.L, 2014. Seasonal surveillance of airborne PCDD/Fs, PCBs and PCNs using passive samplers to assess human health risks. Sci. Total Environ. 466-467, 733-740.

Wania, F., Mackay, D., 1996. Peer reviewed: tracking the distribution of persistent organic pollutants. Environ. Sci. Technol. 30 (9), 390A-396A.

Wannaz, E.D., Abril, G.A., Rodriguez, J.H., Pignata, M.L., 2013. Assessment of polycyclic aromatic hydrocarbons in industrial and urban areas using passive air samplers and leaves of Tillandsia capillaris. J. Environ. Chem. Eng. 1, 1028-1035.

Xu, Q., Zhu, X., Henkelmann, B., Schramm, K.W., Chen, J., Ni, Y., Wang, W., Pfister, G., Mu, J., Qin, S., Li, Y., 2013. Simultaneous monitoring of PCB profiles in the urban air of Dalian, China with active and passive samplings. J. Environ. Sci. 25, 133-143. 